\title{
SKID RESISTANCE PROPERTIES OF AIRFIELD PAVEMENTS AS ONE OF THE SAFETY ASSESSMENT PARAMETERS OF AIR OPERATIONS
}

\author{
WLAŚCIWOŚCI PRZECIWPOŚLIZGOWE \\ NAWIERZCHNI LOTNISKOWYCH JEDNYM \\ Z PARAMETRÓW OCENY BEZPIECZEŃSTWA \\ WYKONYWANIA OPERACJI LOTNICZYCH
}

\author{
Mariusz Wesołowski, Piotr Barszcz, Krzysztof Blacha
}

Air Force Institute of Technology Instytut Techniczny Wojsk Lotniczych

\begin{abstract}
The article presents the method for determining the skid resistance properties by estimating quantities characterizing the conditions on the airfield functional elements' pavements. The skid resistance properties characterise the aircraft' tire grip to the airfield functional element's pavements, and this is the ability to produce a friction force between the airfield functional element's pavement and the aircraft's wheels under mutual skid conditions. The adhesion is affected by the pavement type and its condition, as well as the presence of contamination, and atmospheric conditions in the vicinity of the airfield. Throughout the world, measures aimed at development of a model for assessing the conditions of the airfield functional elements' pavements are undertaken. A key element of this process is the personnel identifying specific situations as well as the pilots using the information for safe manoeuvring, especially landing.
\end{abstract}

Keywords: airfield pavement, friction tester, skid resistance properties

Streszczenie: $W$ artykule przedstawiona została metoda określania właściwości przeciwpoślizgowych poprzez szacowanie wielkości charakteryzujacych warunki panujace na nawierzchniach elementów funkcjonalnych lotnisk. Wtaściwości przeciwpoślizgowe charakteryzuja przyczepność opony statku powietrznego do nawierzchni $i$ jest to zdolność do wytwarzania sity tarcia pomiędzy nawierzchnia elementu funkcjonalnego lotniska a kolami statku powietrznego $w$ warunkach wzajemnego poślizgu. Na przyczepność wpływa rodzaj nawierzchni i jej stan, obecność zanieczyszczeń oraz warunki atmosferyczne $w$ rejonie lotniska. Na calym świecie podejmowane sa działania, które zmierzaja do opracowania modelu oceny warunków panujacych na nawierzchni elementów funkcjonalnych lotnisk. Kluczowym elementem tego procesu jest personel identyfikujacy określone sytuacje oraz piloci wykorzystujący te informacje do bezpiecznego wykonywania manewrów a w szczególności ladowania.

Stowa kluczowe: nawierzchnia lotniskowa, tester tarcia, właściwości przeciwpoślizgowe 
Skid resistance properties of airfield pavements as one of the safety assessment... Wtaściwości przeciwpoślizgowe nawierzchni lotniskowych jednym z parametrów...

\section{SKID RESISTANCE PROPERTIES OF AIRFIELD PAVEMENTS AS ONE OF THE SAFETY ASSESSMENT PARAMETERS OF AIR OPERATIONS}

\section{Introduction}

The skid resistance properties characterise adhesion of an aircraft tyre to the pavement, and this is the ability to produce the friction force between the pavement of the airfield functional element and the aircraft's wheels under conditions of mutual skid. The adhesion is affected by the pavement type and its condition, as well as the presence of contamination, and atmospheric conditions in the vicinity of the airfield. Landing and take-off are the most difficult manoeuvres performed by the pilot controlling the aircraft, and in the case of landing - these are touch down and roll out, but the touch down is a moment of touching the pavement by the aircraft's tyres, and the roll out is deceleration up to the stop or the start of taxiing. The specialists who deal with this problem all over the world strive for the development of a model for assessing the conditions on the airfield functional elements' pavements, including many factors that determine a particular state. A key element of this process is the personnel identifying specific situations as well as the pilots using the information for safe manoeuvring, especially landing. For a long time, attempts have been made to correlate the measurement system's responses with the aircraft's responses obtained under the same conditions. The carried out research allowed to analyse phenomena occurring during deceleration of the aircraft, however, the relationship between the measured friction coefficient and its response was not determined. The assessment of the pavements' skid resistance properties was based on measurement of the friction coefficient, and in many cases, it resulted in a situation that the aircraft crews obtained outdated information, which endangered the safety of air operations, as well as the safety of the crew and passengers. Therefore, a new method for assessing the skid resistance properties [2], which contains ambiguities in terms of defined concepts and the adopted procedure, was offered. Taking this into account, the paper attempted to clarify the terms used in the assessment of conditions on the pavement, and proposed the methodology of their estimation with examples.

\section{Analysis of cause and effect relationships of the improper risk estimation of the safe aircraft stop}

In order to illustrate the cause and effect relationships of the improper risk estimation of the safe stop of operated aircraft, Ishikawa diagram, which helps to separate the causes from the effects of a given situation and see the complexity of the problem, was used. The analysis is started from the conclusion of the effect occurrence and carried out towards identification of all the possible reasons that caused it. 
Among the categories of causes, it is possible to distinguish:

- 5M: Man, Method, Machine, Material, Management,

- 4P: Place, Procedure, People, Policy,

- 4S: Surroundings, Suppliers, Systems, Skills.

Each of these components is broken into individual causes that should be considered individually as problems to be solved. The cause and effect diagram is a graphical analysis of various factors and their interrelationships causing a specific qualitative problem, and an analysis of results caused by the action of these relationships.

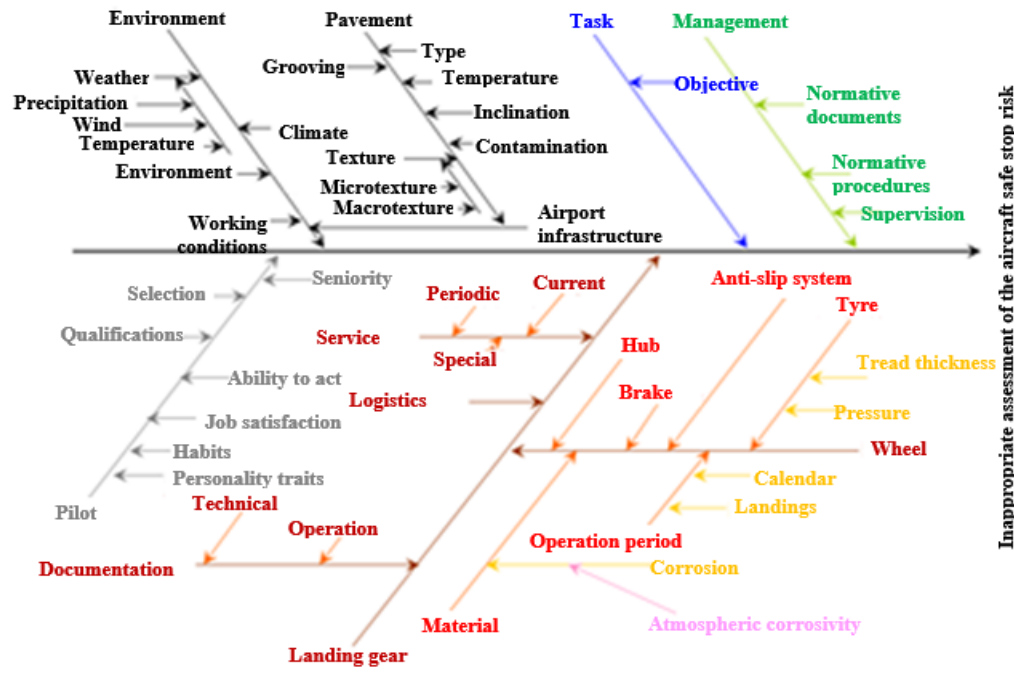

Fig. 1 Ishikawa diagram

In the analysed situation, the main attention was paid to the process of the aircraft stop while landing, and above all, on the impact of phenomena occurring during the operation on its safety risk. As it results from the diagram, the factors that have an impact on the assessment of the aircraft safe stop risk involve a pilot, aircraft's landing gear, including a wheel with a tyre, a wheel hub, a brake and an anti-slip system, as well as weather conditions.

\section{Assessment process of the skid resistance properties of airfield pavements}

The assessment process of the skid resistance properties of the airfield functional elements' pavements covers:

- devices used for measuring the friction coefficient,

- pavements,

- pavement condition,

- aircraft's landing gear,

- contamination,

- atmospheric conditions. 
Skid resistance properties of airfield pavements as one of the safety assessment... Wtaściwości przeciwpoślizgowe nawierzchni lotniskowych jednym z parametrów...

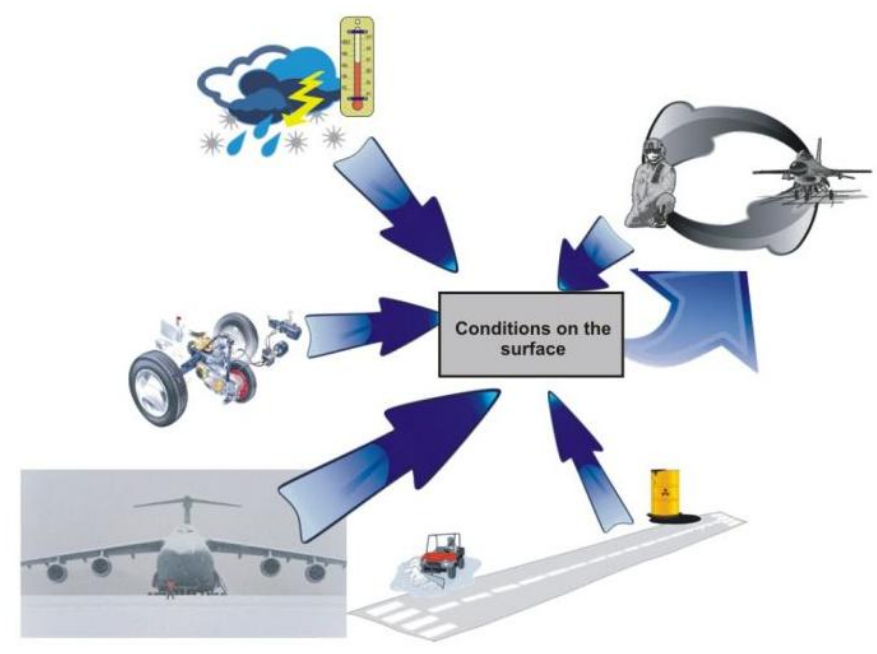

Fig. 2 Characteristics of the skid resistance properties of the airfield functional elements' pavements

For the continuous measurement of the friction coefficient, the Airport Facility [Zakład Lotniskowy] of Air Force Institute of Technology uses T10 trailer friction tester of ASFT Swedish company. This type of tester is equipped with a measuring wheel, which works with a constant longitudinal slip of approx. $13 \%$ and has no mechanical connection to the landing gear, but only with a rear axis with the use of a spring. Such a solution guarantees constant vertical stress on the ground with the value of $1400 \mathrm{~N}$, which ensures the repeatability of the measurement results. T520 measuring tyre with pressure of $700 \mathrm{kPa}$ is made of the appropriately selected material, and it has the shape and tread like the tires used in aircraft. The axis design allows to measure the friction coefficient while driving with the use of a linear actuator with the spring and belt pulley connection, which provides the gentle lowering and raising of the measuring wheel.

The friction coefficient's values provided in Tables 2 and 3 were determined on the basis of data related to friction of the pavement covered with compact snow and ice, and they cannot be regarded as absolute for the use in all weather conditions [1]. If the pavement is covered with snow or ice, and the information that braking is "good" was published, pilots should not expect conditions like on the clean and dry pavement (where friction can be greater than the required one). The term "good" constitutes relative assessment, and means that there should not be difficulties in maintaining the direction or braking, especially during landing.

FAA (Federal Aviation Administration), as well as ICAO (International Civil Aviation Organization) in their provisions, included a collection of the approved devices along with their limit values of friction coefficients determined as: minimum, planned during the use and for new pavements. 
The values of the friction coefficients were determined for two measurement speeds, i.e.: $40 \mathrm{mph}$ (approx. $65 \mathrm{~km} / \mathrm{h}$ ) and $60 \mathrm{mph}$ (approx. $95 \mathrm{~km} / \mathrm{h}$ ), which was presented in Fig. 3.

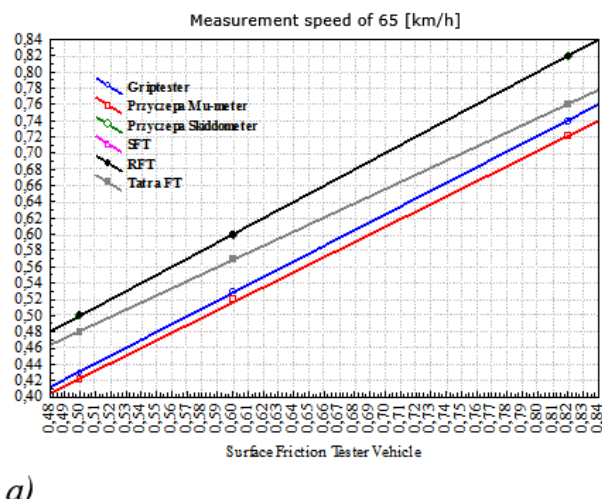

a)

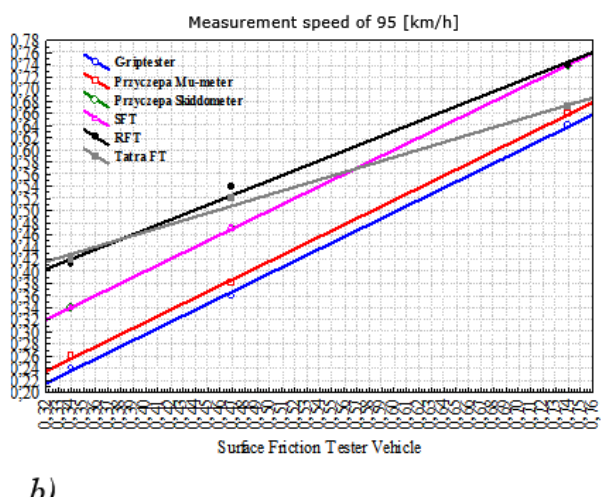

b)

Fig. 3 Friction coefficient's values for different types of devices recommended by ICAO a) measured at the speed of $65 \mathrm{~km} / \mathrm{h} \mathrm{b}$ ) measured at the speed of $95 \mathrm{~km} / \mathrm{h}$

The airfield pavements operated in the Polish Armed Forces were made of asphalt or cement concrete, and their skid resistance properties are affected by their construction and materials, which they were made of, and the types of maintenance procedures that were used within the framework of their operation.

The airfield functional element's pavement may be clean, dry or wet, or covered by atmospheric precipitation or deposits. The airfield functional element's pavement is dry and clean, if there are no contaminants and visible humidity influences on its entire pavement dedicated for using. Dry or clean pavements provide the friction level with slight differences, they are correlated with each other, and they do not require special criteria on the skid resistance properties. The airfield functional element's pavement is wet, when it is soaked with water, but there are no isolated still water bodies and contaminants on it. The phenomenon of the pavement's surface soaking is related to the drainage of water, which is influenced by: shape, surface inclination, tyre-ground contact (macrotexture), and water penetration into the pavement (microtexture).

If the airfield functional element's pavement intended for the use is in $25 \%$ covered with:

- water with the thickness of more than $3 \mathrm{~mm}$, such a pavement is qualified as covered with water,

- snow thicker than $20 \mathrm{~mm}$, such a pavement is qualified as covered with loose snow,

- snow which was compacted to one homogeneous mass, so that the aircraft's wheels move on the pavement's surface without the further snow mass compacting and do not create ruts, such a pavement is qualified as covered with compacted snow, 
Skid resistance properties of airfield pavements as one of the safety assessment... Wtaściwości przeciwpoślizgowe nawierzchni lotniskowych jednym z parametrów...

- snow that contains such a quantity of water that it would be possible to make a well compacted snowball, out of which water cannot be squeezed, such a pavement is qualified as covered with wet snow,

- snow thicker than $3 \mathrm{~mm}$, which is so saturated with water that in case of taking a handful of snow, water comes out of it, and in case of a strong step, it splashes, such a pavement is qualified as covered with melted snow,

- snow thicker than $3 \mathrm{~mm}$, mixed with contaminants, which is so saturated with water that in case of taking a handful of snow, water comes out of it, or in case of a strong step, it splashes, such a pavement is qualified as covered with slush.

The aircraft's landing gear, as a subsystem of the assessment process of the skid resistance properties, consists of struts, shock absorbers, a hub and a tyre, and an anti-slip system.

In the aircraft, the radial tyres, which are characterised by the lower weight with increased durability, are used. By the introduction of tyres with a newer design, it is strived for achieving a compromise between durability and friction. The shape of the tread is selected in order to provide appropriate drainage of water from the area of the tyre-pavement contact.

The wheel hubs are made of light materials such as aluminium alloys and usually forged aluminium alloys. The tyre protection against the blow-out under high temperatures is often applied by using fuses, which smelt after exceeding the critical temperature, and air from the tyre is deflated.

The elements of disc brakes used in aircraft are made of resistant materials with good thermal conduction. The ability of the braking energy absorption is directly related to the type of material and the discs' weight, and the maximum torque depends on the number and diameter of discs, as well as the pressure applied on them. The system's temperature and speed, at which the braking takes place, also have an impact on the maximum torque.

The anti-slip system is a system used in order to prevent the wheels from locking during braking. It prevents from phenomena occurring after locking the wheels, such as the aircraft pulling to one side, and as a result of which the loss of control over it. When the adhesion between the tyre and the pavement decreases to the level, in which the torque will reach the value below the brake's maximum torque, the anti-slip system, which monitors the wheels' slip indicator, regulates pressure on the piston in order to achieve the greatest braking efficiency. The anti-slip system efficiency is determined on the basis of the relation between the average braking force and the theoretical maximum braking force obtained at the optimum slip ratio. 
The airfield pavement contamination is a state resulting from the introduction of solid or liquid substances in such quantities and composition that it could negatively affect the operation safety of aircraft through the deterioration of friction characteristics.

\section{Methodology of the assessment of skid resistance properties}

The assessment of the pavements' skid resistance properties was based on measurement of the friction coefficient so far, and in many cases, it resulted in a situation that the aircraft crews obtained outdated information, which endangered the safety of performing tasks. Therefore, a new method for assessing the skid resistance properties [2], which contains ambiguities in terms of defined concepts and the adopted procedure, was offered.

The proposed method of operation allows to determine the code of conditions on the airfield functional element's pavement, taking into account the weight of features characterising this phenomenon. The experts involved in the assessment of the skid resistance properties of the airfield functional elements' pavements, assigned the weights to individual features, which were presented in Table 1.

Table 1 Weights of characteristics for the assessment of skid resistance properties

\begin{tabular}{|l|c|}
\hline Group & Weight \\
\hline Friction coefficient & 0.39 \\
\hline Pavement state & 0.17 \\
\hline Pavement contamination & 0.10 \\
\hline Atmospheric precipitation and deposits & 0.11 \\
\hline Control over the vehicle & 0.08 \\
\hline Pilot's report & 0.08 \\
\hline Pilot's class & 0.07 \\
\hline
\end{tabular}

Each of the analysed features characterising conditions on the airfield pavement has a different weight, when it comes to the impact on the safety of air operations. The pavement conditions are determined on a scale from 1 to 5 , taking into account the measured friction coefficient, pavement condition, contaminants, precipitation, control over the vehicle, and the pilot's report and class. 
Skid resistance properties of airfield pavements as one of the safety assessment... Właściwości przeciwpoślizgowe nawierzchni lotniskowych jednym z parametrów...

The weighted index characterising conditions on the pavement is determined on the basis of the following formula:

$$
W N_{w}=w_{t} \times W N_{t}+w_{s n} \times W N_{s n}+w_{z} \times W N_{s}+w_{o a} \times W N_{o a}+w_{k p} \times W N_{k p}+w_{r p} \times W N_{r p}+w_{k p} \times W N_{k p}
$$

where:

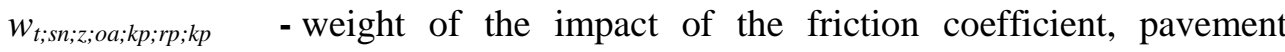
condition, contaminants, precipitation, control over the vehicle, and the pilot's report and class on the assessment of conditions on the airfield pavement;

$W N_{t ; s n ; z ; a ; ; p ; r p ; k p}$ - index characterising conditions on the friction coefficient pavement, pavement condition, contaminants, precipitation, control over the vehicle, and the pilot's report and class.

Table 2 shows the algorithm of conduct while determining the code of conditions on the airfield pavement, where:

- friction coefficient value measured with the use of the airfield friction tester is equal or higher than 0.4 ,

- pavement is covered with compact snow, and the air temperature fluctuates within the range from $-3^{\circ} \mathrm{C}$ to $-13^{\circ} \mathrm{C}$,

- there are contaminants in the form of rubber on the pavement,

- currently, there is no precipitation in the area of the airfield,

- braking or control of the direction is at the average/good level,

- the pilot informs in his report that meteorological conditions occurring during the flight are at the average level,

- the pilot, who sends the message, is a master class.

By acting in accordance with the above mentioned algorithm, it was determined that the code of conditions on the pavement achieved the value of 5 .

Table 3 shows the algorithm of conduct while determining the code of conditions on the pavement, where:

- friction coefficient value measured with the use of the airfield friction tester is equal or lower than 0.25 ,

- pavement is covered with compact snow, and the air temperature fluctuates within the range from $-3^{\circ} \mathrm{C}$ to $-13^{\circ} \mathrm{C}$,

- there are contaminants in the form of rubber on the pavement,

- currently, there is no precipitation in the area of the airfield,

- braking or control of the direction is at the average/good level,

- the pilot informs in his report that meteorological conditions occurring during the flight are at the average level,

- the pilot, who sends the message, is a master class.

By acting in accordance with the above mentioned algorithm, it was determined that the code of conditions on the pavement achieved the value of 3 . 
Mariusz Wesołowski, Piotr Barszcz, Krzysztof Blacha

Table 2 Algorithm of conduct while determining the code of conditions on the airfield pavement

\begin{tabular}{|c|c|c|c|c|c|c|c|}
\hline $\begin{array}{l}\text { Code of } \\
\text { conditions on } \\
\text { the pavement }\end{array}$ & $\begin{array}{l}\text { Friction } \\
\text { coefficient }\end{array}$ & Pavement state & $\begin{array}{c}\text { Pavement } \\
\text { contamination }\end{array}$ & $\begin{array}{c}\text { Atmospheric } \\
\text { precipitation and } \\
\text { deposits }\end{array}$ & Control over the vehicle & Pilot's report & Pilot's class \\
\hline & & Dry & \multirow[b]{2}{*}{ Dust } & \multirow[b]{2}{*}{ None } & \multirow[b]{2}{*}{$\begin{array}{l}\text { Braking or normal } \\
\text { control }\end{array}$} & \multirow[b]{2}{*}{ Good } & \multirow[b]{2}{*}{ M } \\
\hline 5 & $>0.40$ & $\begin{array}{l}\text { Wet (water< } 3 \mathrm{~mm}) \\
\text { Melted snow }(<3 \mathrm{~mm})\end{array}$ & & & & & \\
\hline & & Wet snow $(<3 \mathrm{~mm})$ & & & & & 4 \\
\hline 4 & $0.39 \div 0.36$ & compacted snow $\left(<-13^{\circ} \mathrm{C}\right)$ & $\begin{array}{l}\text { Sand } \\
\text { Deicing } \\
\text { agent }\end{array}$ & Rain & $\begin{array}{l}\text { Braking or control of the } \\
\text { direction at the } \\
\text { average/good level, }\end{array}$ & Good/Average & 1 (1\%5 \\
\hline 3 & $0.35 \div 0.30$ & $\begin{array}{l}\text { Wet } \\
\text { Dry snor } \\
3 \mathrm{~mm})\end{array}$ & Mud & $\begin{array}{l}\text { fnow } \\
\text { Snow grains } \\
\text { Granular snow } \\
\text { Hail } \\
\text { Frost }\end{array}$ & $\begin{array}{l}\text { Significantly reduced } \\
\text { braking or slightly } \\
\text { limited control of the }\end{array}$ & Average & , \\
\hline & & Compacted snow $13^{\circ} \mathrm{C}$ ) & & Rime & & & \\
\hline 2 & $0.29 \div 0.26$ & $\begin{array}{l}\text { Water }(>3 \mathrm{~mm}) \\
\text { Melted snow }(>3 \mathrm{~mm}) \\
\text { Compacted snow }\left(>-3^{\circ} \mathrm{C}\right)\end{array}$ & Rubher & Sleet & $\begin{array}{l}\text { Braking or control of the } \\
\text { direction from the } \\
\text { average to the poor one }\end{array}$ & Average/Poor & 2 \\
\hline 1 & $<0.25$ & Ice & Oil & Freezing sleet & $\begin{array}{l}\text { Braking or significantly } \\
\text { reduced control of the } \\
\text { direction }\end{array}$ & Poor & 3 \\
\hline
\end{tabular}

Table 3 Algorithm of conduct while determining the code of conditions on the airfield pavement

\begin{tabular}{|c|c|c|c|c|c|c|c|}
\hline $\begin{array}{c}\text { Code of } \\
\text { conditions on } \\
\text { the pavement }\end{array}$ & $\begin{array}{l}\text { Friction } \\
\text { coefficient }\end{array}$ & Pavement state & $\begin{array}{l}\text { Pavement } \\
\text { contamination }\end{array}$ & $\begin{array}{l}\text { Atmospheric } \\
\text { precipitation, and } \\
\text { deposits } \\
\end{array}$ & Control over the vehicle & Pilot's report & Pilot's class \\
\hline & & $\begin{array}{l}\text { Dry } \\
\text { Frost }\end{array}$ & & & & & \\
\hline 5 & $>0.40$ & $\begin{array}{l}\text { Melted snow }(<3 \mathrm{~mm}) \\
\text { Dry snow }(<3 \mathrm{~mm}) \\
\text { Wet snow }(<3 \mathrm{~mm}) \\
\end{array}$ & Dust & None & $\begin{array}{l}\text { Braking or normal } \\
\text { control }\end{array}$ & Good & M \\
\hline 4 & $0.39 \div 0.36$ & compacted snow $\left(<-13^{\circ} \mathrm{C}\right)$ & $\begin{array}{l}\text { Sand } \\
\text { Deicing } \\
\text { agent }\end{array}$ & Rain & $\begin{array}{l}\text { Braking or control of the } \\
\text { direction at the } \\
\text { average/good level, }\end{array}$ & Good/Average & $\int(1 \div 5)$ \\
\hline 3 & $0.35 \div 0.3$ & & & $\begin{array}{l}\text { Snow grains } \\
\text { Granular snow }\end{array}$ & $\begin{array}{l}\text { Significantly reduced } \\
\text { braking or slightly }\end{array}$ & & , \\
\hline & & Compacted snow $13^{\circ} \mathrm{C}$ ) & & Rime & & & \\
\hline 2 & $0.29 \div 0.26$ & $\begin{array}{l}\text { Xater }(>3 \mathrm{~mm}) \\
\text { Melted snow }(>3 \mathrm{~mm}) \\
\text { Compacted snow }\left(>-3^{\circ} \mathrm{C}\right)\end{array}$ & Rubber & Sleet & $\begin{array}{l}\text { Braking or control of the } \\
\text { direction from the } \\
\text { average to the poor one }\end{array}$ & Average/Poor & 2 \\
\hline 1 & $<0.25$ & Ice & Oil & Freezing sleet & $\begin{array}{l}\text { Braking or significantly } \\
\text { reduced control of the } \\
\text { direction }\end{array}$ & Poor & 3 \\
\hline
\end{tabular}


Skid resistance properties of airfield pavements as one of the safety assessment... Wtaściwości przeciwpoślizgowe nawierzchni lotniskowych jednym z parametrów...

\section{Conclusion}

The proper determination of the skid resistance properties of the airfield functional elements' pavements is an important element of the aircraft's deceleration process, because it directly affects the safety of air operations and the safety of the crew and passengers.

The increase in the number of air operations forces the carrier to perform works aimed developing the assessment model of the skid resistance properties, taking into account the friction coefficient measured with the use of specialised hardware, such as friction testers.

The conditions on the pavement may change in a short period of time, therefore, while determining the skid resistance properties, it is important to take into account the friction coefficient, pavement conditions, pavement contamination, atmospheric precipitation and deposits, control over the vehicle, and the pilot's report and class. The friction testers used for measuring the friction coefficient of the airfield functional elements' pavements should be included, or the results of their measurements should be correlated with the results of measurements of the measuring devices, which were listed in Annex No. 14 ICAO to the Convention on the international civil aviation.

\section{References}

[1] Annex 14 ICAO to the Convention on the international civil aviation. Airports. Volume I Design and operation of airports. Sixth edition, 2013.

[2] Official Journal of the Civil Aviation Office Wytyczne Nr 2 Prezesa Urzędu Lotnictwa Cywilnego z dnia 25 stycznia 2016 r. w sprawie metod oceny, pomiaru oraz raportowania stanu nawierzchni drogi startowej [Official Journal of the Civil Aviation Office Guidelines No. 2 of the President of the Civil Aviation Office of 25 January 2016 on the methods of assessment, measurement and reporting the runway surface condition].

[3] Grigoriu M.: Expert systems for maintenance engineering, Materiały Konferencji Artificial Techniques for Improving Aicraft Maitenance Efficiency, London 1991.

[4] Jaźwiński J., Borgoń J.: Niezawodność eksploatacyjna i bezpieczeństwo lotów [Operational reliability and safety of flights], Eds. KiŁ Warsaw 1989.

[5] Lewitowicz J., Borgoń J., Ząbkowicz W.: Problemy badań i eksploatacji techniki lotniczej [Problems of research and aircraft technology operation], Eds. Air Force Institute of Technology, Warsaw 1993.

[6] Sobol E. - Editor of the volume: Słownik wyrazów obcych [Dictionary of foreign words], Wydawnictwo Naukowe PWN, Warsaw 1999. 
[7] Wesołowski M., Barszcz P., Blacha K.: Ocena testerów tarcia przeprowadzona na podstawie badań porównawczych współczynnika tarcia nawierzchni wybranych odcinków lotnisk usytuowanych w Powidzu, Poznaniu-Krzesinach i Radomiu [Evaluation of friction testers executed on the basis of comparative tests of the friction coefficient of selected airfield sections' surfaces in Powidz, Poznań Krzesiny i Radom], In: Report No. 30/24/2014, Air Force Institute of Technology, 2014.

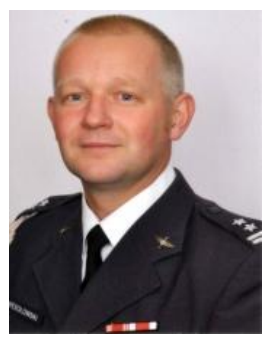

Lt. Col. Mariusz Wesolowski, Ph.D. Eng., a graduate of the Military University of Technology and the Warsaw University of Technology. Head of the Airport Department of Air Force Institute of Technology. His specialisation is design, construction, and assessment of the technical condition of the airfield pavement structures.

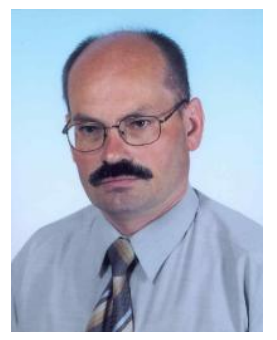

Piotr Barszcz, Ph.D. Eng., a graduate of the Military University of Technology. An assistant professor in the Airport Department in Air Force Institute of Technology. His specialisation is the issue of corrosion, reliability, safety, and operation of aircraft. He participates in the works aimed at the development and implementation of the system of airfield pavement management.

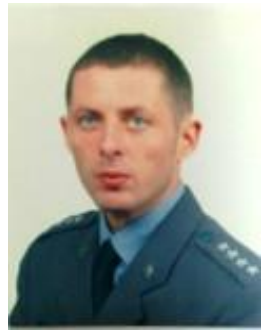

Capt. Krzysztof Blacha, MSc Eng., a graduate of the Faculty of Military Engineering of the Military Academy of Land Forces and of the Faculty of Civil Engineering and Geodesy of the Military University of Technology. An assistant in the Airport Department in Air Force Institute of Technology. His specialisation is design, construction and assessment of the technical condition of the airfield pavement structures. 
Skid resistance properties of airfield pavements as one of the safety assessment... Wtaściwości przeciwpoślizgowe nawierzchni lotniskowych jednym z parametrów...

\section{WLAŚCIWOŚCI PRZECIWPOŚLIZGOWE NAWIERZCHNI LOTNISKOWYCH JEDNYM Z PARAMETRÓW OCENY BEZPIECZEŃSTWA WYKONYWANIA OPERACJI LOTNICZYCH}

\section{Wstęp}

Właściwości przeciwpoślizgowe charakteryzują przyczepność opony statku powietrznego do nawierzchni i jest to zdolność do wytwarzania siły tarcia pomiędzy nawierzchnią elementu funkcjonalnego lotniska a kołami statku powietrznego w warunkach wzajemnego poślizgu. Na przyczepność wpływa rodzaj nawierzchni i jej stan, obecność zanieczyszeń oraz warunki atmosferyczne w rejonie lotniska. Lądowanie i start są najtrudniejszymi manewrami wykonywanymi przez pilota sterującego statkiem powietrznym, a w przypadku lądowania jest to przyziemienie i dobieg, przy czym przyziemienie jest to moment dotknięcia nawierzchni przez opony statku powietrznego a dobieg jest to wytracanie prędkości aż do zatrzymania się bądź rozpoczęcia kołowania. Specjaliści zajmujący się tym problemem na całym świecie dążą do opracowania modelu oceny warunków panujących na nawierzchniach elementów funkcjonalnych lotnisk przy uwzględnieniu wielu czynników, które warunkują określony stan. Kluczowym elementem tego procesu jest personel identyfikujący określone sytuacje oraz piloci wykorzystujący te informacje do bezpiecznego wykonywania manewrów a w szczególności lądowania. Od dłuższego czasu podejmowane są próby skorelowania odpowiedzi systemu pomiarowego $\mathrm{z}$ odpowiedzią statku powietrznego uzyskanymi w tych samych warunkach. Przeprowadzone badania pozwoliły przeanalizować zjawiska zachodzące podczas wytracania prędkości przez statek powietrzny, jednak nie określono związku pomiędzy zmierzonym współczynnikiem tarcia a jego odpowiedzią. Jak do tej pory ocena właściwości przeciwpoślizgowych nawierzchni opierała się na pomiarze współczynnika tarcia, w wielu przypadkach doprowadzało to do sytuacji, kiedy załogi statków powietrznych otrzymywały nieaktualne informacje, co zagrażało bezpieczeństwu wykonywania operacji lotniczych oraz bezpieczeństwu załogi i pasażerów. Dlatego też zaproponowano nowy sposób oceny właściwości przeciwpoślizgowych [2], który jednak zawiera niejasności w zakresie zdefiniowanych pojęć i przyjętej metody postępowania. Mając to na uwadze w artykule starano się uściślić pojęcia wykorzystywane przy ocenie warunków panujących na nawierzchni oraz zaproponowano metodologię ich szacowania wraz z przykładami. 


\section{Analiza związków przyczynowo-skutkowych nieprawidłowego oszacowania ryzyka bezpiecznego zatrzymania statku powietrznego}

W celu zilustrowania związków przyczynowo-skutkowych niewłaściwego oszacowania ryzyka bezpiecznego zatrzymywania eksploatowanych statków powietrznych wykorzystano diagram Ishikawy, który pomaga oddzielić przyczyny od skutków danej sytuacji i dostrzec złożoność problemu. Analiza rozpoczynana jest od stwierdzenia wystąpienia skutku i prowadzona w kierunku identyfikacji wszystkich możliwych przyczyn, które go spowodowały.

Wśród kategorii przyczyn można wymienić:

- 5M: Man (czowiek), Method (metoda), Machine (maszyna), Material (materiał), Management (zarządzanie),

- 4P: Place (miejsce), Procedure (zasady), People (pracownicy), Policy (polityka/zasady),

- 4S: Surroundings (otoczenie), Suppliers (dostawcy), Systems (system), Skills (umiejetności).

Każda $\mathrm{z}$ tych składowych jest rozbijana na poszczególne przyczyny, które powinny być rozpatrywane indywidualnie jako problemy do rozwiązania. Diagram przyczynowo-skutkowy jest graficzną analizą wpływu różnych czynników oraz ich wzajemnych powiązań wywołujących określony problem jakościowy oraz analizą rezultatów spowodowanych działaniem tych powiązań.

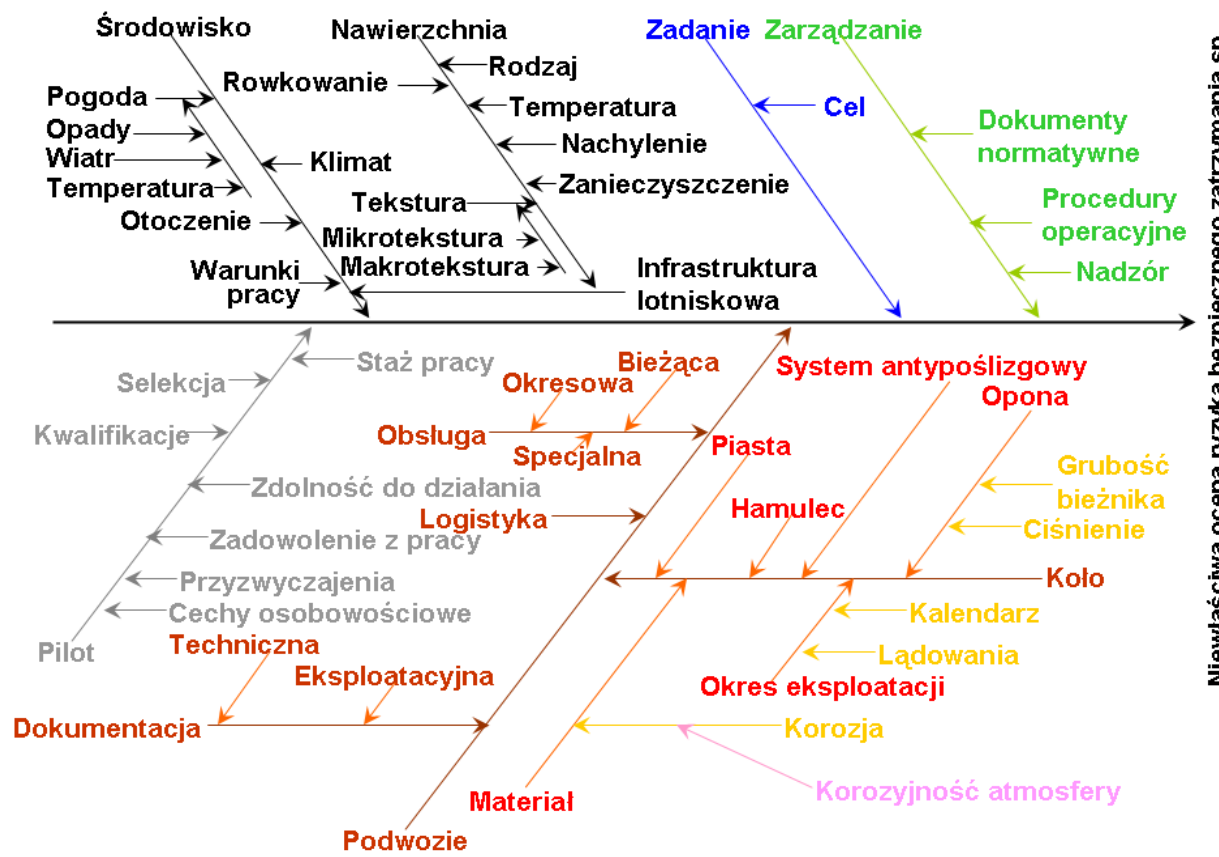

Rys. 1 Diagram Ishikawy 
Skid resistance properties of airfield pavements as one of the safety assessment... Wtaściwości przeciwpoślizgowe nawierzchni lotniskowych jednym z parametrów...

$\mathrm{W}$ analizowanej sytuacji główną uwagę zwrócono na proces zatrzymania statku powietrznego przy lądowaniu a przede wszystkim na wpływ zjawisk zachodzących podczas eksploatacji na jego ryzyko bezpieczeństwa. Jak wynika z diagramu czynnikami, które wpływają na ocenę ryzyka bezpiecznego zatrzymania statku powietrznego jest pilot, podwozie statku powietrznego a w tym koło wraz z oponą, piastą, hamulcem i systemem antypoślizgowym a także warunki atmosferyczne.

\section{Proces oceny wlaściwości przeciwpoślizgowych nawierzchni lotniskowych}

Proces oceny właściwości przeciwpoślizgowych nawierzchni elementów funkcjonalnych lotnisk obejmuje swoim zakresem:

- urządzenia służące do pomiaru współczynnika tarcia,

- nawierzchnie,

- stan nawierzchni,

- podwozie statku powietrznego,

- zanieczyszczenia,

- warunki atmosferyczne.

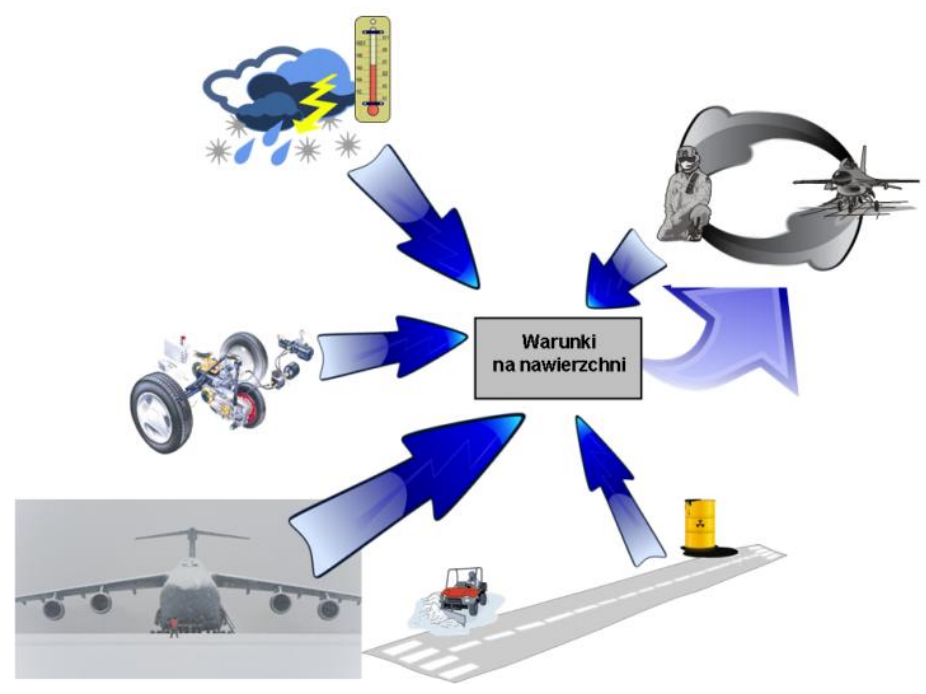

Rys. 2 Cechy charakteryzujące właściwości przeciwpoślizgowe nawierzchni elementów funkcjonalnych lotnisk

Do ciągłego pomiaru współczynnika tarcia Zakład Lotniskowy ITWL wykorzystuje przyczepowy tester tarcia T10 szwedzkiej firmy ASFT. Tego rodzaju tester wyposażony jest $\mathrm{w}$ koło pomiarowe, które pracuje ze stałym podłużnym poślizgiem wynoszącym około $13 \%$ i nie ma połączenia mechanicznego $\mathrm{z}$ podwoziem a tylko $\mathrm{z}$ tylną osią za pomocą sprężyny. Takie rozwiązanie gwarantuje stały, pionowy nacisk na podłoże o wartości $1400 \mathrm{~N}$, co zapewnia powtarzalność wyników pomiarów. 
Opona pomiarowa typu T520 o ciśnieniu $700 \mathrm{kPa}$ wykonana jest $\mathrm{z}$ odpowiednio dobranego materiału, posiada kształt i bieżnik podobnie, jak opony stosowane na statkach powietrznych. Konstrukcja osi pozwala na wykonywanie pomiarów współczynnika tarcia podczas jazdy przy wykorzystaniu siłownika liniowego wraz ze sprężyną i połączeniem pasowym, co zapewnia łagodne opuszczanie i podnoszenie koła pomiarowego.

Wartości współczynnika tarcia zamieszczone w tabelach 2 i 3 zostały określone na podstawie danych dotyczących tarcia nawierzchni pokrytej ubitym śniegiem lub lodem, nie można uważać tych wartości jako bezwzględne do stosowania we wszystkich warunkach pogodowych [1]. Jeżeli nawierzchnia pokryta jest śniegiem lub lodem oraz opublikowano informację, że hamowanie jest „dobre”, piloci nie powinni spodziewać się warunków takich jak na czystej i suchej nawierzchni (gdzie tarcie może być dużo większe niż wymagane). Określenie „dobre” jest oceną względną i oznacza, że nie powinny wystąpić trudności w utrzymaniu kierunku lub hamowaniu, zwłaszcza podczas lądowania.

FAA (Federal Aviation Administration), jak i ICAO (International Civil Aviation Organization) w swoich przepisach zawarły zbiór aprobowanych przez siebie urządzeń wraz z uzyskanymi przez nie granicznymi wartościami współczynników tarcia określanymi jako: minimalne, planowane podczas użytkowania oraz dla nowych nawierzchni. Wartości współczynników tarcia zostały określone dla dwóch prędkości pomiaru, tj.: $40 \mathrm{mph}$ (ok. $65 \mathrm{~km} / \mathrm{h}$ ) oraz $60 \mathrm{mph}$ (ok. $95 \mathrm{~km} / \mathrm{h}$ ), co przedstawiono na rysunku 3.

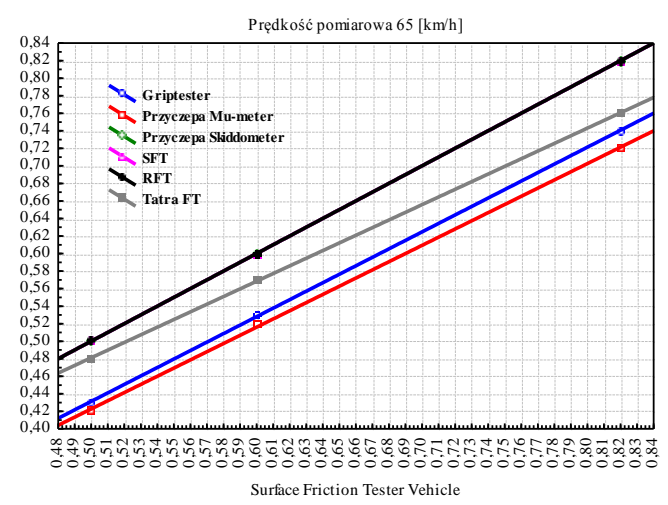

a)

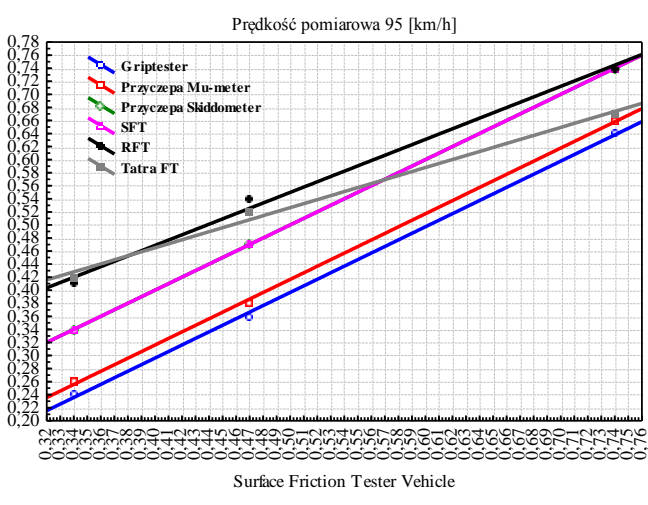

b)

Rys. 3 Wartości współczynnika tarcia dla różnego rodzaju urzadzeń rekomendowanych przez ICAO a) mierzone przy prędkości $65 \mathrm{~km} / \mathrm{h}$ b) mierzone przy prędkości $95 \mathrm{~km} / \mathrm{h}$ 
Skid resistance properties of airfield pavements as one of the safety assessment... Wtaściwości przeciwpoślizgowe nawierzchni lotniskowych jednym z parametrów...

Nawierzchnie lotniskowe eksploatowane w Siłach Zbrojnych RP zostały wykonane $\mathrm{z}$ betonu asfaltowego lub cementowego, a na ich właściwości przeciwpoślizgowe ma wpływ ich konstrukcja i materiały, z jakich zostały one wykonane a także, jakie zabiegi utrzymaniowe były stosowane w ramach ich eksploatacji.

Nawierzchnia elementu funkcjonalnego lotniska może być w stanie suchym, czystym, mokrym lub może być pokryta opadami czy osadami atmosferycznymi. Nawierzchnia elementu funkcjonalnego lotniska (EFL) jest sucha i czysta, jeżeli na całej jej powierzchni przeznaczonej do użytkowania nie znajdują się zanieczyszczenia i widoczne ślady wilgoci. Nawierzchnie suche lub czyste zapewniają poziom tarcia o nieznacznych różnicach, są ze sobą skorelowane i nie są dla nich wymagane szczególne kryteria dotyczące właściwości przeciwpoślizgowych. Powierzchnia nawierzchni EFL jest mokra, kiedy jest nasiąknięta wodą, ale nie znajdują się na niej zastoiska wody i zanieczyszczenia. Zjawisko nasiąkania powierzchni nawierzchni związane jest $\mathrm{z}$ odprowadzaniem wody, na który ma wpływ: kształt, nachylenie powierzchni, styk opona-ziemia (makrotekstura), wnikanie wody w nawierzchnię (mikrotekstura).

Jeżeli powierzchnia nawierzchni EFL przeznaczonej do użytkowania jest w 25\% pokryta:

- wodą o grubości ponad $3 \mathrm{~mm}$, taką nawierzchnię kwalifikuje się jako pokryta wodą,

- śniegiem o grubości większej niż 20 mm, taką nawierzchnię kwalifikuje się jako pokryta luźnym śniegiem,

- śniegiem, który został zagęszczony do jednolitej masy tak, że koła statku powietrznego poruszają się na powierzchni nawierzchni bez dalszego zagęszczania masy śniegu oraz nie tworzą kolein, taką nawierzchnię kwalifikuje się jako pokryta ubitym śniegiem,

- śniegiem, który zawiera taką ilość wody, aby można było z niego zrobić dobrze zagęszczoną kulę śnieżną, z której nie można wycisnąć wodę, taką nawierzchnię kwalifikuje się jako pokryta mokrym śniegiem,

- śniegiem o grubości ponad $3 \mathrm{~mm}$, który jest tak nasycony wodą, że w przypadku wzięcia garstki śniegu wypływa z niego woda lub przy silnym nadepnięciu stopą chlapie, taką nawierzchnię kwalifikuje się jako pokryta roztajałym śniegiem,

- śniegiem o grubości ponad 3 mm wymieszanym z zanieczyszczeniami, które są tak nasycony wodą, że w przypadku wzięcia garstki śniegu wymieszanego z zanieczyszczeniami wypływa z niego woda lub przy silnym nadepnięciu stopą chlapie, taką nawierzchnię kwalifikuje się jako pokryta błotem pośniegowym. 
Podwozie statku powietrznego jako podsystem procesu oceny właściwości przeciwpoślizgowych składa się $\mathrm{z}$ goleni, amortyzatora, piasty i opony oraz z systemu antypoślizgowego.

$\mathrm{Na}$ statkach powietrznych stosuje się opony radialne, które charakteryzują się mniejszym ciężarem przy zwiększonej trwałości. Wprowadzając opony o nowszej konstrukcji dąży się do osiągnięcia kompromisu pomiędzy trwałością a tarciem. Kształt bieżnika dobiera się w taki sposób, aby było zapewnione właściwe odprowadzenie wody z obszaru styku opona - nawierzchnia.

Piasty kół wykonywane są z materiałów lekkich takich jak stopy aluminium i zazwyczaj z kutych stopów aluminium.

Często stosuje się zabezpieczenie opony przed rozsadzeniem pod wpływem wysokich temperatur poprzez stosowanie bezpieczników, które przy przekroczeniu temperatury krytycznej wytapiają się i zostaje wypuszczone powietrze z opony.

Elementy hamulców tarczowych stosowanych na statkach powietrznych wykonuje się $\mathrm{z}$ materiałów wytrzymałych i dobrze przewodzących ciepło. Zdolność pochłaniani energii hamowania jest bezpośrednio związana $\mathrm{z}$ rodzajem materiału i masą tarcz, maksymalny moment obrotowy zależy od liczby i średnicy tarcz, jak również od nacisku wywieranego na nie. Temperatura układu oraz prędkość, przy której następuje hamowanie mają również wpływ na maksymalny moment obrotowy.

System antypoślizgowy jest układem stosowanym w celu przeciwdziałania blokowaniu kół podczas hamowania. Zapobiega on zjawiskom występującym po zablokowaniu kół, takim jak ściąganie samolotu w bok a w efekcie utrata kontroli nad nim. Gdy zmniejsza się przyczepność pomiędzy oponą a nawierzchnią do poziomu, w którym moment obrotowy osiągnie wartość poniżej maksymalnego momentu obrotowego hamulca, to system antypoślizgowy monitorujący wskaźnik poślizgu kół reguluje ciśnienie na tłoku w celu osiągnięcia najlepszej skuteczności hamowania. Skuteczność systemu antypoślizgowego określa się w oparciu o stosunek pomiędzy średnią siłą hamowania a teoretyczną maksymalną siłą hamowania uzyskaną przy optymalnym współczynniku poślizgu.

Zanieczyszczenie nawierzchni lotniskowej jest to stan wynikający z wprowadzenia substancji stałych lub ciekłych w takich ilościach i takim składzie, że może to ujemnie wpływać na bezpieczeństwo eksploatacji statków powietrznych poprzez pogorszenie charakterystyk tarcia.

\section{Metodologia oceny właściwości przeciwpoślizgowych}

Jak do tej pory ocena właściwości przeciwpoślizgowych nawierzchni opierała się o pomiar współczynnika tarcia, w wielu przypadkach doprowadzało to do sytuacji, w której załogi statków powietrznych otrzymywały nieaktualne informacje, 
Skid resistance properties of airfield pavements as one of the safety assessment... Wtaściwości przeciwpoślizgowe nawierzchni lotniskowych jednym z parametrów...

co zagrażało bezpieczeństwu wykonywania zadania. Dlatego też zaproponowano nowy sposób oceny właściwości przeciwpoślizgowych [2], który zawiera niejasności w zakresie zdefiniowanych pojęć i przyjętej metody postępowania.

Zaproponowany sposób działania pozwala na określenie kodu warunków panujących na nawierzchni elementu funkcjonalnego lotniska uwzględniając wagi cech charakteryzujących to zjawisko. Eksperci zajmujący się oceną właściwości przeciwpoślizgowych nawierzchni elementów funkcjonalnych lotnisk nadali wagi poszczególnym cechom, które to przedstawiono w tabeli 1 .

Tabela 1. Wagi cech do oceny kodu właściwości przeciwpoślizgowych

\begin{tabular}{|l|c|}
\hline \multicolumn{1}{|c|}{ Grupa } & Waga \\
\hline Współczynnik tarcia & 0,39 \\
\hline Stan nawierzchni & 0,17 \\
\hline Zanieczyszczenie nawierzchni & 0,10 \\
\hline Opady, osady atmosferyczne & 0,11 \\
\hline Kontrola nad pojazdem & 0,08 \\
\hline Raport pilota & 0,08 \\
\hline Klasa pilota & 0,07 \\
\hline
\end{tabular}

Każda $\mathrm{z}$ analizowanych cech charakteryzujących warunki panujące na nawierzchni lotniska ma inną wagę, jeżeli chodzi o wpływ na bezpieczeństwo wykonywania operacji lotniczych. Warunki na nawierzchni określa się w skali od 1 do 5, biorąc pod uwagę zmierzony współczynnik tarcia, stan nawierzchni, zanieczyszczenia, opady atmosferyczne, kontrolę nad pojazdem, raport i klasę pilota. Wskaźnik ważony charakteryzujący warunki panujące na nawierzchni określa się w oparciu o wzór:

$W N_{w}=w_{t} \times W N_{t}+w_{s n} \times W N_{s n}+w_{z} \times W N_{s}+w_{o a} \times W N_{o a}+w_{k p} \times W N_{k p}+w_{r p} \times W N_{r p}+w_{k p} \times W N_{k p}$

gdzie:

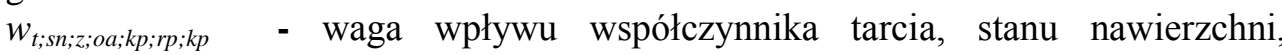
zanieczyszczeń, opadów atmosferycznych, kontroli nad pojazdem, raportu i klasy pilota na ocenę warunków panujących na nawierzchni lotniska;

$W N_{t ; s n ; z ; o a ; k p ; r p ; k p}$ - wskaźnik charakteryzujący warunki panujące na nawierzchni dla współczynnika tarcia, stanu nawierzchni, zanieczyszczeń, opadów atmosferycznych, kontroli nad pojazdem, raportu i klasy pilota.

W tabeli 2 przedstawiono algorytm postępowania przy określaniu kodu warunków panujących na nawierzchni lotniskowej, gdzie:

- wartość współczynnika tarcia zmierzona z wykorzystaniem lotniskowego testera tarcia jest równa lub większa niż 0,4 , 
- nawierzchnia pokryta jest ubitym śniegiem, a temperatura powietrza waha się w przedziale $-3^{\circ} \mathrm{C}$ do $-13^{\circ} \mathrm{C}$,

- na nawierzchni znajdują się zanieczyszczenia w postaci gumy,

- aktualnie w rejonie lotniska nie występują opady atmosferyczne,

- hamowanie lub kontrola kierunku na poziomie średnia/dobra,

- pilot komunikuje w swoim raporcie, że warunki metrologiczne występujące podczas lotu są na poziomie średnim,

- pilot, który przesyła komunikat jest klasy mistrzowskiej.

Postępując zgodnie z przedstawionym powyżej algorytmem określono, że kod warunków na nawierzchni osiągnął wartość 5 .

W tabeli 3 przedstawiono algorytm postępowania przy określaniu kodu warunków panujących na nawierzchni, gdzie:

- wartość współczynnika tarcia zmierzona z wykorzystaniem lotniskowego testera tarcia jest równa lub mniejsza niż 0,25 ,

- nawierzchnia pokryta jest ubitym śniegiem, a temperatura powietrza waha się w przedziale $-3^{\circ} \mathrm{C}$ do $-13^{\circ} \mathrm{C}$,

- na nawierzchni znajdują się zanieczyszczenia w postaci gumy,

- aktualnie w rejonie lotniska nie występują opady atmosferyczne,

- hamowanie lub kontrola kierunku na poziomie średnia/dobra,

- pilot komunikuje w swoim raporcie, że warunki metrologiczne występujące podczas lotu są na poziomie średnim,

- pilot, który przesyła komunikat jest klasy mistrzowskiej.

Postępując zgodnie z przedstawionym powyżej algorytmem określono, że kod warunków na nawierzchni osiągnął wartość 3 .

Tabela 2. Algorytm postępowania przy określaniu kodu warunków panujacych na nawierzchni lotniskowej

\begin{tabular}{|c|c|c|c|c|c|c|c|}
\hline $\begin{array}{c}\text { Kod } \\
\text { warunków na } \\
\text { nawierzchni }\end{array}$ & $\begin{array}{l}\text { Wspóiczynnik } \\
\text { tarcia }\end{array}$ & Stan nawierzchni & $\begin{array}{c}\text { Zanieczyszczenia } \\
\text { nawierzchni }\end{array}$ & $\begin{array}{l}\text { Opady, osady } \\
\text { atmosferyczne }\end{array}$ & $\begin{array}{l}\text { Kontrola nad } \\
\text { pojazdem }\end{array}$ & Raport pilota & $\begin{array}{l}\text { Klasa } \\
\text { pilota }\end{array}$ \\
\hline \multirow{2}{*}{ 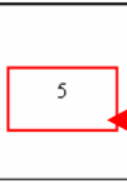 } & \multirow[b]{2}{*}{$>0,40$} & \multirow{2}{*}{$\begin{array}{l}\text { Sucha } \\
\text { Mróz } \\
\text { Mokra (woda }<3 \mathrm{~mm}) \\
\text { Roztajaly śnieg }(<3 \\
\text { Suchy śnieg }(<3 \mathrm{~mm}) \\
\text { Mokry śnieg }(<3 \mathrm{~mm}) \\
\end{array}$} & \multirow[b]{2}{*}{ Kurz } & \multirow[b]{2}{*}{ Brak } & \multirow[b]{2}{*}{ 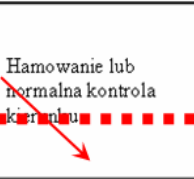 } & \multirow[b]{2}{*}{$\begin{array}{l}\text { Dobre } \\
\|= \pm=1\end{array}$} & \multirow[b]{2}{*}{$\frac{M_{0}^{M}}{T}$} \\
\hline & & & & & & & \\
\hline 4 & $0,39 \div 0,36$ & Ubity śnieg $\left(<-13^{\circ} \mathrm{C}\right)$ & $\begin{array}{l}\text { Piasek } \\
\text { Srodek } \\
\text { odladzający }\end{array}$ & Deszcz & $\begin{array}{l}\text { Hamowanie lub } \\
\text { kontrola kierunku na } \\
\text { poziomie } \\
\text { średnia/dobra } \\
\end{array}$ & Dobre/Średnie & $1(1-5$ lat $)$ \\
\hline \multirow{3}{*}{3} & \multirow{3}{*}{$0,35 \div 0,30$} & \multirow{3}{*}{$\begin{array}{l}\text { Mokrt } \\
\text { Suchy snieg }(>3 \mathrm{~mm}) \\
\text { Mokry sntleg }(>3 \mathrm{~mm}) \\
\text { Ubity snieg }\left(-3^{\circ} \mathrm{C}--\right. \\
\left.13^{\circ} \mathrm{C}\right)\end{array}$} & \multirow{3}{*}{ Bloto } & \multirow{3}{*}{\begin{tabular}{|l} 
Snieg \\
Snieg ziarnisty \\
Krupy \\
Grad \\
Szron \\
Szadź \\
\end{tabular}} & \multirow{3}{*}{$\begin{array}{l}\text { Hamowanie znacznie } \\
\text { zmniejszone lub } \\
\text { kontrola kierunku } \\
\text { nieznacznie } \\
\text { ograniczona }\end{array}$} & $y$ & \multirow{3}{*}{1} \\
\hline & & & & & & Średnie & \\
\hline & & & & & & & \\
\hline 2 & $0,29 \div 0,26$ & $\begin{array}{l}\text { Woda (>3 mm) } \\
\text { Roztajaly śnieg }(>3 \\
\text { mm) } \\
\text { Ubity śnieg }\left(>-3^{\circ} \mathrm{C}\right)\end{array}$ & Guma & $\begin{array}{l}\text { Deszcz ze } \\
\text { śniegiem }\end{array}$ & $\begin{array}{l}\text { Hamowanie lub } \\
\text { kontrola kierunku od } \\
\text { średniej do złej }\end{array}$ & Średnie/Zle & 2 \\
\hline 1 & $<0,25$ & Lód & Olej & $\begin{array}{l}\text { Marznący } \\
\text { deszcz ze } \\
\text { śniegiem }\end{array}$ & $\begin{array}{l}\text { Hamowanie lub } \\
\text { kontrola kierunku } \\
\text { znacznie ograniczona }\end{array}$ & Zle & 3 \\
\hline
\end{tabular}


Skid resistance properties of airfield pavements as one of the safety assessment... Właściwości przeciwpoślizgowe nawierzchni lotniskowych jednym z parametrów...

Tabela 3. Algorytm postępowania przy określaniu kodu warunków panujacych na nawierzchni lotniskowej

\begin{tabular}{|c|c|c|c|c|c|c|c|}
\hline $\begin{array}{c}\text { Kod } \\
\text { warunków na } \\
\text { nawierzchni }\end{array}$ & $\begin{array}{l}\text { Wspólczynnik } \\
\text { tarcia }\end{array}$ & Stan nawierzchni & $\begin{array}{c}\text { Zanieczyszczenia } \\
\text { nawierzchni }\end{array}$ & $\begin{array}{l}\text { Opady, osady } \\
\text { atmosferyczne }\end{array}$ & $\begin{array}{l}\text { Kontrola nad } \\
\text { pojazdem }\end{array}$ & Raport pilota & $\begin{array}{l}\text { Klasa } \\
\text { pilota }\end{array}$ \\
\hline \multirow{3}{*}{5} & \multirow{3}{*}{$>0,40$} & \multirow{3}{*}{$\begin{array}{l}\text { Sucha } \\
\text { Mróz } \\
\text { Mokra (woda }<3 \mathrm{~mm}) \\
\text { Roztajaly śnieg }(<3 \\
\text { mm) } \\
\text { Suchy śnieg }(<3 \mathrm{~mm}) \\
\text { Mokry śnieg }(<3 \mathrm{~mm})\end{array}$} & \multirow{3}{*}{ Kurz } & & \multirow{3}{*}{$\begin{array}{l}\text { Hamowanie lub } \\
\text { normalna kontrola } \\
\text { kierunku }\end{array}$} & \multirow{3}{*}{ Dobre } & \multirow[b]{2}{*}{ M } \\
\hline & & & & $\begin{array}{l}\text { Brak } \\
\text { Inzawkay }\end{array}$ & & & \\
\hline & & & & & & & $\uparrow$ \\
\hline 4 & $0,39 \div 0,36$ & Ubity śnieg $\left(<-13^{\circ} \mathrm{C}\right)$ & $\begin{array}{l}\text { Piasek } \\
\text { Srodek } \\
\text { odladzający }\end{array}$ & Dfszcz & \begin{tabular}{|l|} 
Hamowanie lub \\
kontrola kierunku na \\
poziomie \\
średnia/dobra \\
\end{tabular} & Dobre/Średnie & 1 (1-5 lat) \\
\hline \multirow{3}{*}{3} & \multirow{3}{*}{$0,35 \div 0,30$} & \multirow{3}{*}{$\begin{array}{l}\text { Mokra } \\
\text { Suchy śnieg (> } 3 \mathrm{~mm}) \\
\text { Mokry śnieg (>3 mm) } \\
\begin{array}{l}\text { Dblly } \\
\left.13^{\circ} \mathrm{C}\right)\end{array} \\
\end{array}$} & \multirow{3}{*}{ Bloto } & \multirow{3}{*}{\begin{tabular}{|l|} 
Snieg \\
Snieg ziarnisty \\
Krupy \\
Grad = = = . \\
Szron \\
Szadź \\
\end{tabular}} & \multirow{3}{*}{ 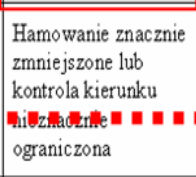 } & $y$ & \multirow{3}{*}{$\mid \begin{array}{c}1 \\
0\end{array}$} \\
\hline & & & & & & Średnie & \\
\hline & & & & & & 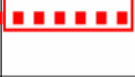 & \\
\hline 2 & $0,29 \div 0,26$ & $\begin{array}{l}\text { Woda }(>3 \mathrm{~mm}) \\
\text { Rentajaly śnieg }(>3 \\
\text { mm) } \\
\text { Ubity śnieg }\left(>-3^{\circ} \mathrm{C}\right)\end{array}$ & Guma & $\begin{array}{l}\text { Deszcz ze } \\
\text { śniegiem }\end{array}$ & $\begin{array}{l}\text { Hamowanie lub } \\
\text { kontrola kierunku od } \\
\text { śedniej do zlej }\end{array}$ & Średnie/Zle & 2 \\
\hline 1 & $<0,25$ & Lód & Olej & $\begin{array}{l}\text { Marznący } \\
\text { deszcz ze } \\
\text { śniegiem }\end{array}$ & $\begin{array}{l}\text { Hamowanie lub } \\
\text { kontrola kierunku } \\
\text { znacznie ograniczona }\end{array}$ & Zle & 3 \\
\hline
\end{tabular}

\section{Podsumowanie}

Prawidłowe określanie właściwości przeciwpoślizgowych nawierzchni elementów funkcjonalnych lotnisk jest ważnym elementem procesu wytracania prędkości przez statek powietrzny, gdyż od tego bezpośrednio zależy bezpieczeństwo wykonywania operacji lotniczych oraz bezpieczeństwo załogi i pasażerów Zwiększanie liczby operacji lotniczych wymusza na przewoźniku prowadzenie prac mających na celu opracowanie modelu oceny właściwości przeciwpoślizgowych przy uwzględnieniu współczynnika tarcia mierzonego z wykorzystaniem wyspecjalizowanego sprzętu jakim są testery tarcia.

Warunki panujące na nawierzchni mogą ulec zmianie w krótkim czasie, dlatego też przy określaniu właściwości przeciwpoślizgowych powinno się uwzględniać współczynnik tarcia, stan nawierzchni, zanieczyszczenie nawierzchni, opady i osady atmosferyczne, kontrolę nad pojazdem, raport i klasę pilota.

Testery tarcia stosowane do pomiaru współczynnika tarcia nawierzchni elementów funkcjonalnych lotnisk powinny być zamieszczone, lub wyniki ich pomiarów powinny być skorelowane $\mathrm{z}$ wynikami pomiarów urządzeń pomiarowych, które zostały wyszczególnione $\quad \mathrm{w}$ załączniku $\mathrm{Nr} \quad 14$ ICAO do konwencji o międzynarodowym lotnictwie cywilnym. 


\section{Literatura}

[1] Załącznik 14 ICAO do konwencji o międzynarodowym lotnictwie cywilnym. Lotniska. Tom I Projektowanie i eksploatacja lotnisk. Wydanie szóste, 2013.

[2] Dziennik Urzędowy Urzędu Lotnictwa Cywilnego. Wytyczne Nr 2 Prezesa Urzędu Lotnictwa Cywilnego z dnia 25 stycznia 2016 r. w sprawie metod oceny, pomiaru oraz raportowania stanu nawierzchni drogi startowej.

[3] Grigoriu M.: Expert systems for maintenance engineering, Materiały Konferencji Artificial Techniques for Improving Aicraft Maitenance Efficiency, London 1991.

[4] Jaźwiński J., Borgoń J.: Niezawodność eksploatacyjna i bezpieczeństwo lotów, Wyd. KiŁ Warszawa 1989.

[5] Lewitowicz J., Borgoń J., Ząbkowicz W.: Problemy badań i eksploatacji techniki lotniczej, Wyd. ITWL, Warszawa 1993.

[6] Sobol E. - Redaktor tomu: Słownik wyrazów obcych, Wydawnictwo Naukowe PWN, Warszawa 1999.

[7] Wesołowski M., Barszcz P., Blacha K.: Ocena testerów tarcia przeprowadzona na podstawie badań porównawczych współczynnika tarcia nawierzchni wybranych odcinków lotnisk usytuowanych w Powidzu, Poznaniu-Krzesinach i Radomiu, W: Sprawozdanie Nr 30/24/2014, ITWL, $2014 \mathrm{r}$.

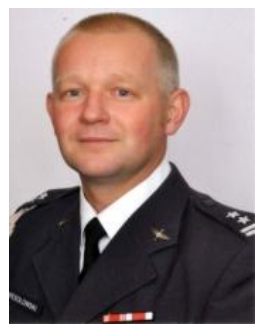

Pptk dr inz. Mariusz Wesolowski, absolwent Wojskowej Akademii Technicznej i Politechniki Warszawskiej. Kierownik Zakładu Lotniskowego w Instytucie Technicznym Wojsk Lotniczych. Specjalizuje się w projektowaniu, budowie i ocenie stanu technicznego konstrukcji nawierzchni lotniskowych (Udziat 35\%).

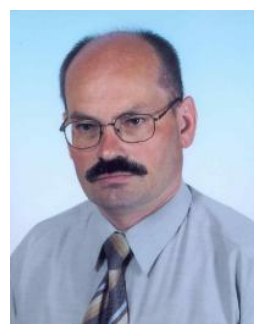

Dr inz. Piotr Barszcz, absolwent Wojskowej Akademii Technicznej. Adiunkt $w$ Instytucie Technicznym Wojsk Lotniczych. Specjalizuje się w tematyce korozji, niezawodności, bezpieczeństwa i eksploatacji statków powietrznych. Uczestniczy $w$ pracach majacych na celu opracowanie $i$ wdrożenie do eksploatacji systemu zarzadzania nawierzchniami lotniskowymi (Udziat 35\%).

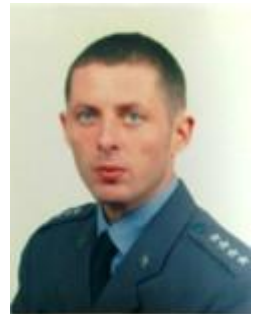

Kpt. mgr inz. Krzysztof Blacha, absolwent Wydziatu Inżynierii Wojskowej Wyższej Szkoty Oficerskiej Wojsk Ladowych i Wydziatu Inżynierii Ladowej i Geodezji Wojskowej Akademii Technicznej. Asystent w Zakladzie Lotniskowym w Instytucie Technicznym Wojsk Lotniczych. Specjalizuje sie $w$ projektowaniu, budowie $i$ ocenie stanu technicznego konstrukcji nawierzchni lotniskowych (Udziat 30\%). 